\title{
PERAN IBU-IBU DALAM MEWASPADAI PENIPUAN BELANJA ONLINE DI MEDIA SOSIAL
}

\author{
Ari Dermawan ${ }^{1}$, Amalia $^{2}$, Sudarmin $^{3}$ \\ ${ }^{1)}$ Manajemen Informatika, STMIK Royal Kisaran \\ ${ }^{2,3)}$ Sistem Informatika, STMIK Royal Kisaran \\ email: ${ }^{1)}$ aridermawan451@gmail.com, ${ }^{2)}$ amelkhana90@gmail.com, ${ }^{3)}$ edisudarmindra@gmail.com
}

\begin{abstract}
Abstrak
Internet atau interconnection networking merupakan media penting dalam kehidupan sehari-hari dan memberikan banyak manfaat khususnya informasi lebih cepat dan mudah di dapatkan. Manfaat tersebut menjadikan internet sebagai media yang menghubungkan manusia di seluruh belahan dunia untuk berinteraksi tanpa batas. Transaksi e-commerce atau belanja di Toko Online memungkinkan terjadinya penipuan dalam menjualkan barang atau produk yang ditawarkan. Banyak jenis penipuan yang terjadi di dalam transaksi e-commerce atau belanja di Toko Online termasuk penipuan dalam bentuk gambar yang di jual. Banyaknya permasalahan yang timbul dalam transaksi jual beli di Toko Online seperti iklan suatu barang atau produk tidak sesuai dengan gambar atau wujud asli serta realitanya, sampai kepada barang atau jasa tidak diterima konsumen, dan lain sebagainya. Undang-undang nomor 11 Tahun 2008 adalah UU yang mengatur tentang informasi serta transaksi elektronik, atau teknologi informasi secara umum. UU ini memiliki yurisdiksi yang berlaku untuk setiap orang yang melakukan perbuatan hukum sebagaimana diatur dalam Undang-Undang ini, baik yang berada di wilayah Indonesia maupun di luar wilayah hukum Indonesia, yang memiliki akibat hukum di wilayah hukum Indonesia dan/atau di luar wilayah hukum Indonesia dan merugikan kepentingan Indonesia.
\end{abstract}

Kata kunci: Penipuan, Online

\begin{abstract}
Internet or interconnection networking is an important medium in everyday life and provides many benefits, especially information that is faster and easier to get. These benefits make the internet a medium that connects people in all parts of the world to interact without boundaries. E-commerce or shopping transactions at Online Stores allow fraud in selling the goods or products offered. Many types of fraud that occur in e-commerce transactions or shopping at Online Stores, including fraud in the form of images that are sold. The number of problems that arise in buying and selling transactions at Online Stores, such as advertisements for goods or products that do not match the original image or form and reality, to the goods or services not accepted by consumers, and so on Law number 11 of 2008 is the law that regulates information and electronic transactions, or information technology in general. This law has jurisdiction that applies to every person who commits a legal act as regulated in this Law, whether in the territory of Indonesia or outside the jurisdiction of Indonesia, which has legal consequences in the jurisdiction of Indonesia and / or outside the jurisdiction of Indonesia. and detrimental to Indonesia's interests.
\end{abstract}

Keywords: Fraud, Online

\section{PENDAHULUAN}

Internet menjadi salah satu kebutuhan untuk manusia saat ini, hal ini karena memang segalanya kini berhubungan dengan internet. Bukan hanya untuk hiburan, internet juga kini bisa digunakan menjadi salah satu media belanja, pembelajaran, pekerjaan dan banyak hal lainnya. Dengan kebutuhan yang semakin kompleks dan internet mempermudah semua hal itu, maka internet menjadi kebutuhan manusia yang tidak bisa dipisahkan lagi. Untuk mendapatkan internet, saat ini merupakan hal yang sangat mudah. Ini berbeda dengan beberapa tahun lalu, dimana internet masih menjadi barang langkah dan juga masih sangat mahal. Saat ini, ada banyak pilihan pengguna internet untuk menggunakan jasa provider khususnya untuk internet dari smartphone yang digunakan. 
UU ITE sudah cukup komprehensif dalam mengatur informasi elektronik dan transaksi elektronik. Hal ini dapat dilihat dari beberapa cakupan materi UU ITE yang merupakan terobosan baru yang sudah dijelaskan sebelumnya. Beberapa hal yang belum diatur secara spesifik diatur dalam UU ITE, akan diatur dalam Peraturan Permerintah dan peraturan perundang-undangan lainnya.

Manfaat UU. No 11 Tahun 2008 tentang ITE, yaitu :

a) Menjamin kepastian hukum bagi masyarakat yang melakukan transaksi secara elektronik.

b) Mendorong pertumbuhan ekonomi Indonesia.

c) Sebagai salah satu upaya mencegah terjadinya kejahatan berbasis teknologi informasi.

d) Melindungi masyarakat pengguna jasa dengan memanfaatkan teknologi informasi.

e) Internet atau interconnection networking merupakan media penting dalam kehidupan sehari-hari dan memberikan banyak manfaat khususnya informasi lebih cepat dan mudah di dapatkan. Manfaat tersebut menjadikan internet sebagai media yang menghubungkan manusia di seluruh belahan dunia untuk berinteraksi tanpa batas. Menurut Alvin Toffler, dengan adanya internet itu memunculkan julukan "Masyarakat Gelombang Ketiga". Maksud dari julukan tersebut adalah masyarakat dengan hadirnya internet mengalami perubahan signifikan pada tiga dimensi kemanusiaan mereka, yaitu Perilaku Manusia (human action), Interaksi antar Manusia (human interaction), dan Hubungan antar Manusia (human relations).

f) Dalam era globalisasi saat ini, banyak bermunculan model-model bisnis dengan menggunakan kecanggihan teknologi modern. Hal ini di tandai dengan berkembangnya media teknologi yang mempengaruhi aspek kehidupan manusia, khususnya dalam berteransaksi jual beli melalui online, yakni internet, peran internet saat ini bukan hanya aktifitas komunikasi, namun juga sebagai alat pencari informasi. Alat-alat komunikasi seperti komputer, laptop, smartphone sangat memudahkan masyarakat untuk melakukan koneksi dengan internet untuk melakukan teransaksi jual beli.

g) Dalam perkembangannya, perubahan model dan pola interaksi manusia memasuki wilayah hubungan dagang atau bisnis. Hadirnya internet dirasakan pelaku bisnis membawa banyak manfaat salah satunya transaksi lebih mudah, cepat, praktis, dan juga harga yang lebih terjangkau sehingga hubungan bisnis menjadi lebih efisien. Perdagangan dengan memanfaatkan teknologi internet ini yang dikenal dengan istilah electronic commerce atau yang disingkat menjadi e-commerce.

E-commerce dipercaya memiliki potensi sangat besar untuk mengembangkan volume bisnis di dunia maya dan akan terus berkembang secara signifikan. Pihak penjual dalam transaksi e-commerce terus memanfaatkan internet sebagai media andalan dalam mentransfer informasi, barang atau jasa tertentu, dengan cepat dan murah, antar negara maupun lintas negara. Sebaliknya, pihak pembeli dapat mencari barang atau jasa sesuai yang diperlukan secara efiesien, dengan menghemat waktu, tenaga, serta biaya yang dikeluarkan.

Proses transaksi jual beli online pada dasarnya tidak jauh berbeda dengan proses transaksi jual beli secara langsung. Transaksi secara online menggunakan kontrak jual beli yang disebut kontrak elektronik. Kontrak elektronik adalah perjanjian para pihak yang dibuat melalui sistem elektronik. Dengan demikian suatu transaksi online harus memenuhi syarat sahnya perjanjian sebagaiman di tentukan dalam Pasal 1320 KUHP perdata, yaitu adanya kesepakatan kedua belah pihak, kecakapan untuk melakukan perbuatan hukum, adanya objek, dan adanya kausa yang halal.

Disamping banyaknya keuntungan atau manfaat yang dirasakan masyarakat, munculnya transaksi $e$ commerce tidak mungkin tidak menimbulkan permasalahan. Menurut seorang pembeli, memilih bertransaksi e-commerce yang menawarkan transaksi jual beli secara praktis merupakan pilihan cerdas. Akibatnya sering kali pembeli lupa bahwa transaksi e-commerce tidak luput dari bahaya. Berdasarkan penjelasan Undangundang No. 11 Tahun 2008 tentang Informasi dan Transaksi Elektronik Pasal 1 Ketentuan Umum angka 2, dijelaskan transaksi elektronik adalah perbuatan hukum yang dilakukan dengan menggunakan komputer, jaringan komputer, dan/atau media elektronik lainnya.

Tolak ukur kontrak atau perjanjian agar dapat dinyatakan sah oleh hukum yaitu dengan memenuhi syarat sah perjanjian, apabila tidak memenuhi unsur tersebut maka sering terjadi permasalahan baik itu penipuan maupun hal-hal yang dilarang oleh hukum. Jika kita melihat pada Pasal 1320 KUHP Perdata sebagai instrumen penguji keabsahan kontrak yang dibuat oleh para pihak memiliki 4 syarat sah yang harus dipenuhi, yakni :

1. Kata sepakat bagi mereka yang mengikatkan diri dalam perjanjian;

2. Kecakapan para pihak yang membuat perikatan 
3. Adanya suatu hal tertentu; dan

4. Terdapat sebab yang halal atau diperbolehkan.

Di dalam transaksi e-commerce atau belanja di Toko Online memungkinkan terjadinya penipuan dalam menjualkan barang atau produk yang ditawarkan. Banyak jenis penipuan yang terjadi di dalam transaksi $e$ commerce atau belanja di Toko Online termasuk penipuan dalam bentuk gambar yang di jual. Banyaknya permasalahan yang timbul dalam transaksi jual beli di Toko Online seperti iklan suatu barang atau produk tidak sesuai dengan gambar atau wujud asli serta realitanya, sampai kepada barang atau jasa tidak diterima konsumen, dan lain sebagainya. Hal-hal tersebut menuai protes dari pembeli selaku konsumen yang pada akhirnya pihak pembeli meminta pertanggung jawaban kepada pelaku usaha. Pertanggung jawaban itu sering kali berupa permintaan ganti rugi dengan pengembalian sejumlah uang yang sudah dibayarkan konsumen kepada pelaku usaha, atau apabila yang di beli berupa jasa, maka complain yang diajukan untuk meminta service sesuai yang dijanjikan pelaku usaha di dalam iklan yang dibuatnya.

Karena dalam trasaksi jual beli e-commerce, iklan ibarat janji yang diberikan kepada pembeli. Melalui iklan itulah pelaku usaha dapat mempromosikan serta menawarkan berbagai macam produk maupun jasa sehingga menarik minat konsumen. Iklan termasuk sebagai dokumen elektronik sebagaimana yang dinyatakan di dalam Undang-Undang No. 11 Tahun 2008 tentang Informasi dan Transaksi Elektronik Pasal 1 angka 4 bahwa, yaitu: "Dokumen Elektronik adalah setiap Informasi Elektronik yang dibuat, diteruskan, dikirimkan, diterima, atau disimpan dalam bentuk analog, digital, elektromagnetik, optikal, atau sejenisnya, yang dapat dilihat, ditampilkan, dan/atau didengar melalui Komputer atau Sistem Elektronik, termasuk tetapi tidak terbatas pada tulisan, suara, gambar, peta, rancangan, foto atau sejenisnya, huruf, tanda, angka, Kode Akses, simbol atau perforasi yang memiliki makna atau arti atau dapat dipahami oleh orang yang mampu memahaminya”.

Berdasarkan Undang-Undang No. 11 Tahun 2008 tentang Informasi dan Transaksi Elektronik Pasal 1 angka 17, kontrak yang dibuat melalui sistem elektronik disebut dengan Kontrak Elektronik. Sehingga transaksi elektronik yang dituangkan dalam kontrak elektronik mengikat kepada para pihaknya, seperti yang diatur di dalam Pasal 18 ayat (1) Undang-Undang No. 11 Tahun 2008 tentang Informasi dan Transaksi elektronik. Untuk itu, apabila pelaku usaha tidak dapat mempertanggung jawabkan janji- janji yang ada di dalam iklan yang ia buat, maka pelaku usaha dapat di katakan wanpretasi terhadap pembeli selaku konsumen karena tidak dapat memenuhi prestasi. Janji-janji di dalam iklan tidak hanya merupakan deskripsi barang tetapi juga mengenai jangka waktu sampainya barang, kekurangan- kekurangan yang terdapat pada produk dan/atau jasa, dan lain sebagainya.

Kasus penipuan online menjadi salah satu kasus yang sekarang marak terjadi, apalagi sekarang semakin berkembangnya zaman, alat-alat elektronik juga semakin canggih. Dengan semakin canggihnya alat-alat elektronik masyarakat semakin mudah untuk mengakses internet. Dahulu, masyarakat menggunakan internet masih sangat terbatas, mengakses internet hanya bisa dilakukan oleh masyarakat yang berada di kota-kota besar saja, dikarenakan keterbatasan sinyal dan kurangnya pengetahuan tentang teknologi di daerah pedesaan atau perkampungan, sehingga mereka sulit untuk mengakses internet dan memahami teknologi. Berbeda dengan sekarang, masyarakat dari segala kalangan baik di desa maupun di kota dapat menggunakan internet untuk berbagai macam hal. Kalangan tua, muda, sampai anak-anak sekarang mampu menggunakannya untuk kebutuhanya. Kasus penipuan online pada prinsipnya sama dengan penipuan konvensional. Yang membedakan hanyalah pada sarana perbuatannya yakni menggunakan sistem elektronik. Penipuan online juga dapat dirumuskan sebagai suatu kejahatan secara hukum karena tindakan yang dilakukan dapat merugikan seseorang dan juga peraturan ini tercantum dalam hukum pidana dan lagi pelakunya dikenakan sanksi hukuman yang jelas.

\section{METODE}

Kegiatan sosialisasi Peran Ibu-Ibu dalam Mewaspadai Penipuan Belanja Online di Media Sosial diselenggarakan dilakukan dalam tiga tahapan sebagai berikut:

\section{Tahap Persiapan}

Pada tahap ini dilakukan kegiatan pertemuan dengan kordinator wilayah Kecamatan Teluk Dalam dari Dinas P2KBP3A Kab. Asahan. Pihak Kecamatan Teluk Dalam dengan menjelaskan tentang adanya pemberian sosialisasi kepada masyarakat yaitu ibu-ibu terkait dengan visi misi tim dalam pelaksanaan Tri Dharma 
Perguruan Tinggi, berkoordinasi dengan pihak Kecamatan Teluk Dalam mengenai sasaran peserta, syarat peserta, jumlah peserta, tempat Pembagian tugas kepada anggota tim, penyusunan materi dan persiapan pendukung lainnya.

\section{Tahap Pelaksanaan}

Pelaksanaan pelatihan ditujukan kepada 35 orang peserta atau masyarakat yang terdiri dari ibu-ibu. Kegiatan ini dilakukan dengan melakukan tatap muka interaktif dengan peserta, menggunakan media pembelajaran slide/power point untuk memudahkan para ibu-ibu memahami materi sosialisasi.

\section{Tahap Evaluasi}

Pada tahap evaluasi dilakukan penilaian keberhasilan peserta menangkap materi sosialisasi yang dilaksanakan di Kecamatan Teluk Dalam dari Dinas P2KBP3A Kab. Asahan. Para peserta diberikan kuesioner mengenai hal-hal berkaitan Peran Ibu-Ibu dalam Mewaspadai Penipuan Belanja Online di Media Sosial untuk melihat sejauh mana pemahaman Para peserta terhadap materi yang telah disampaikan. Kuesioner yang diberikan berisikan pertanyaan-pertanyaan tertutup.

\section{HASIL DAN PEMBAHASAN}

Undang-Undang Nomor 11 Tahun 2008 tentang Informasi dan Transaksi Elektronik sebagaimana telah diubah oleh Tahun 2008 tentang Informasi dan Transaksi Elektronik tidak secara khusus mengatur mengenai tindak pidana penipuan. Selama ini, tindak pidana penipuan sendiri diatur dalam Pasal 378 KUHP Pidana, dengan rumusan pasal sebagai berikut :"Barangsiapa dengan maksud untuk menguntungkan diri sendiri atau orang lain secara melawan hukum dengan menggunakan nama palsu atau martabat (hoedaningheid) palsu; dengan tipu muslihat, ataupun rangkaian kebohongan, menggerakkan orang lain untuk menyerahkan barang sesuatu kepadanya, atau supaya memberi utang maupun menghapuskan piutang, diancam, karena penipuan, dengan pidana penjara paling lama empat tahun."

Walaupun Undang-Undang Nomor 11 Tahun 2008 tentang Informasi dan Transaksi Elektronik dan perubahannya tidak secara khusus mengatur mengenai tindak pidana penipuan, namun terkait dengan timbulnya kerugian konsumen dalam transaksi elektronik terdapat ketentuan Pasal 28 ayat (1) Undang-Undang Nomor 11 Tahun 2008 tentang Informasi dan Transaksi Elektronik yang menyatakan : "Setiap Orang dengan sengaja, dan tanpa hak menyebarkan berita bohong dan menyesatkan yang mengakibatkan kerugian konsumen dalam Transaksi Elektronik."

Terhadap pelanggaran Pasal 28 ayat (1) Undang-Undang Nomor 11 Tahun 2008 tentang Informasi dan Transaksi Elektronik ini diancam pidana sebagaimana diatur dalam Pasal 45A ayat (1) Undang-Undang Nomor 11 Tahun 2008 tentang Informasi dan Transaksi Elektronik, yakni: "Setiap Orang yang dengan sengaja dan tanpa hak menyebarkan berita bohong dan menyesatkan yang mengakibatkan kerugian konsumen dalam Transaksi Elektronik sebagaimana dimaksud dalam Pasal 28 ayat (1) dipidana dengan pidana penjara paling lama 6 (enam) tahun dan/atau denda paling banyak Rp 1.000.000.000,00 (satu miliar rupiah)."

Rumusan-rumusan Pasal 28 ayat (1) Undang-Undang Nomor 11 Tahun 2008 tentang Informasi dan Transaksi Elektronik dan Pasal 378 KUHP Pidana tersebut dapat kita ketahui bahwa keduanya mengatur hal yang berbeda. Pasal 378 KUHPidana mengatur penipuan. Sementara Pasal 28 ayat (1) Nomor 11 Tahun 2008 tentang Informasi dan Transaksi Elektronik mengatur mengenai berita bohong yang menyebabkan kerugian konsumen dalam transaksi elektronik.

Kegiatan jual beli online saat ini semakin marak, apalagi situs yang di gunakan untuk melakukan transaksi jual beli online ini semakin baik dan beragam. Namun, seperti yang kita ketahui bahwa dalam sistem jual beli produk yang di tawarkan hanya berupa penjelasan spesifikasi barang dan gambar yang tidak bisa dijamin kebenarannya. Untuk itu sebagai pembeli, maka sangat penting untuk mencari tahu kebenaran apakah barang yang ingin di beli itu sudah sesuai atau tidak. Menurut Kamus Besar Bahasa Indonesia, jual beli adalah persetujuan saling mengikat antar penjual, yakni pihak yang menyerahkan barang, dan pembeli sebagai pihak yang membayar harga barang yang di jual.

Dalam transaksi jual beli online, penjual dan pembeli tidak bertemu langsung dalam satu tempat melainkan melalui dunia maya. Adapun yang menjadi subjek jual beli online tidak berbeda dengan jual beli secara konvensional, yaitu pelaku usaha selaku penjual yang menjual barangnya dan pembeli sebagai konsumen yang membayar harga barang. Adapun yang menjadi objek jual beli online, yaitu barang atau jasa yang dibeli oleh konsumen, namun barang atau jasa tidak dilihat langsung oleh pembeli selaku subjek jual beli online. Sangat berbeda dengan jual beli secara konvensional dimana penjual dan pembeli dapat bertemu dan melihat objek 
jual beli secara langsung, sehingga memungkinkan pembeli mendapatkan kepastian terkait dengan kualitas barang yang ingin dibelinya, sehingga sangat minim terjadi tindakan penipuan.

Dalam mekanisme jual beli online hal pertama yang di lakukan oleh konsumen, yaitu mengakses situs tertentu dengan cara masuk ke alamat website toko online yang menawarkan penjualan barang. Setelah masuk dalam situs itu, konsumen tinggal melihat menunya dan memilih barang apa yang ingin dibeli. Misalnya, jam tangan, klik jam tangan, merek apa yang di sukai, klik dan pilih harga yang cocok, lalu klik sudah cocok, bisa dilakukan dengan transaksi dengan menyetujui perjanjian yang telah ditetapkan oleh kedua belah pihak. Terjadi kesepakatan secara digital pelaku usaha akan mengirimkan nomor rekening dan alamatnya pada konsumen dan setelah itu konsumen menunggu barangnya sekitar seminggu.

Adapun saat ini dengan berbagai macam media sosial seperti WA, facebook, line, blackberry dan lainnya. Konsumen tinggal melihat postingan pelaku usaha berupa gambar-gambar produk yang ditawarkan kepada konsumen, lalu kemudian konsumen tinggal mengkonfirmasi lewat komentar, inbox atau sms dan telepon jika ingin memesan barang yang diinginkan. Biasannya digambar itu telah tertera nomor rekening pelaku usaha, sehingga setelah mengkonfirmasi pelaku usaha, maka konsumen bisa langsung mentransfer uangnya lewat bank, lalu mengirimkan bukti trasfernya ke pelaku usaha, setelah itu konsumen menunggu barang yang di belinya paling cepat biasannya dalam waktu seminggu.

Konsumen jual beli online semakin dituntut untuk mengetahui lebih dalam mengenai proses, resiko serta keamanan dari sebuah transaksi online, Saat ini jenis transaksi online juga semakin beragam mulai dari jenis konvensional di mana pembeli dan penjual harus bertatap muka dalam melakukan proses transaksi hingga yang menggunakan proses transaksi otomatis tanpa harus bertatap muka. Di Indonesia sendiri ada beberapa jenis teransaksi jual beli online yang biasa di lakukan oleh konsumen jual beli online, yaitu :

a. Transfer Antar Bank, Transaksi dengan cara transfer antar bank merupakan jenis transaksi yang paling umum dan populer digunakan oleh para penjual online. Selain cukup simple, jenis transaksi ini juga memudahkan proses konfirmasi karena dana bisa dengan cepat di cek oleh penerima dana/penjual. Prosesnya adalah pertama pembeli mengirim dana yang telah disepakati lalu setelah dana masuk, maka penjual akan mengirimkan barang transaksi yang dijanjikan. Kekurangan transaksi antar bank adalah diperlukannya kepercayaan yang tinggi dari para pembeli sebelum memutuskan mengirim dana.

b. COD (Cash On Delivery)Pada sistem COD sebenarnya masih menganut cara lama yaitu dengan bertemu antara penjual dan pembeli. Biasanya sistem transaksi ini dilakukan dalam jual beli antar orang ke orang dan pada umumnya COD digunakan untuk barang second karena pembeli harus memeriksa dengan baik keadaan barang tersebut. Keuntungan dari sistem ini adalah antara penjual dan pembeli lebih bisa leluasa dalam proses transaksi.

c. Rekening Bersama (Rekber), Jenis transaksi jual beli online yang terakhir adalah dengan menggunakan rekening bersama atau yang juga disebut dengan istilah escrow. Cara pembayaran ini sedikit berbeda dengan proses pembayaran melalui transfer bank. Jika dalam transfer bank, pihak ketiga nya adalah bank, sedangkan dengan sistem Rekber yang menjadi pihak ketiga adalah lembaga pembayaran yang telah dipercaya baik oleh pihak penjual maupun pembeli.

\section{SIMPULAN}

Kesimpulan dari Kegiatan Pengabdian Masyarakat ini adalah : Dapat memberikan manfaat untuk Kepada masyarakat khususnya ibu-ibu di Kecamatan teluk terkait penipuan belanja online di media sosial.

\section{DAFTAR PUSTAKA}

H.M. Arsyad Sanusi, 2011, Hukum E-Commerce, Sasrawarna Printing, Jakarta Pusat

Agus Yudha Hernoko, , 2010Hukum Perjanjian (Asas Proporsionaliras dalam Kontrak Komersial) Edisi I,

Ctk. Pertama, Kencana Prenada Media Group, Jakarta

Depdiknas, 2008, Kamus Besar Bahasa Indonesia, Gramedia Pustaka, Jakarta

Rie, E-Commerce, https://bpptik.kominfo.go.id/2014/12/19/645/e-commerce/

https://smart-telecom.co.id/2018/05/15/kebutuhan-internet-jaman-now/

https://www.maxmanroe.com/3-jenis-transaksi-jual-beli-online-terpopuler-di-indonesia.html 